\title{
DNA barcoding for assessment of exotic molluscs associated with maritime ports in northern Iberia
}

\section{Ivana Pejovic, Alba Ardura, Laura Miralles, Andres Arias, Yaisel J. Borrell \& Eva Garcia-Vazquez}

To cite this article: Ivana Pejovic, Alba Ardura, Laura Miralles, Andres Arias, Yaisel J. Borrell \& Eva Garcia-Vazquez (2016) DNA barcoding for assessment of exotic molluscs associated with maritime ports in northern Iberia, Marine Biology Research, 12:2, 168-176, DOI: 10.1080/17451000.2015.1112016

To link to this article: http://dx.doi.org/10.1080/17451000.2015.1112016

曲 Published online: 01 Mar 2016.

Submit your article to this journal $\asymp$

View related articles $₫$

View Crossmark data $₫$ 


\title{
DNA barcoding for assessment of exotic molluscs associated with maritime ports in northern Iberia
}

\author{
Ivana Pejovic ${ }^{a}$, Alba Ardura $^{b}$, Laura Miralles ${ }^{a}$, Andres Arias $^{c}\left(\mathbb{D}\right.$, Yaisel J. Borrell ${ }^{\mathrm{a}}$ and Eva Garcia-Vazquez ${ }^{\mathrm{a}}$ \\ ${ }^{\mathrm{a} D e p a r t m e n t}$ of Functional Biology, University of Oviedo, Oviedo, Spain; ${ }^{\mathrm{b} C e n t r e ~ d e ~ R e c h e r c h e ~ I n s u l a i r e ~ e t ~ O b s e r v a t o i r e ~ d e ~ I ' E n v i r o n n e m e n t ~}$ \\ (CRIOBE), Papetoai, Moorea, French Polynesia; 'Department of Biology of Organisms and Systems, University of Oviedo, Oviedo, Spain
}

\begin{abstract}
Ports are gateways for aquatic invasions. New arrivals from maritime traffic and disturbed environmental conditions can promote the settlement of exotic species. Molluscs fall into the most prevalent group of invasive species and can have a tremendous impact on aquatic ecosystems. Here we have investigated exotic molluscs in three ports with different intensities of maritime traffic in the Cantabrian Sea. DNA barcodes were employed to identify the species using BLASTn and BOLD IDS assignment. Deep morphological analysis using diagnostic criteria confirmed BLAST species assignation based on COI and 16S rRNA genes. Results confirmed the usefulness of DNA barcoding for detecting exotic species that are visually similar to native species. Three exotic bivalves were identified: Ostrea stentina (dwarf oyster), the highly invasive Crassostrea gigas (Pacific oyster) and Xenostrobus securis (pygmy mussel). This is the first record of $O$. stentina in the Bay of Biscay and the second of $X$. securis in the Cantabrian Sea. Furthermore, we report on the presence of the cryptogenic mussel Mytilaster minimus in the central Cantabrian Sea. These exotic species might have been overlooked due to their phenotypic similarity with co-occurring oyster and mussel species. This study illustrates how combining morphological and DNA taxonomic analysis can help in port and marina biosecurity surveys.
\end{abstract}

\section{ARTICLE HISTORY}

Received 28 May 2015

Accepted 15 October 2015

Published online 1 March

2016

\section{RESPONSIBLE EDITOR}

Rachel Collin

\section{KEYWORDS}

Exotic molluscs; NIS; ports; northern Iberia; cryptic species; DNA barcoding; diagnostic criteria

\section{Introduction}

When people first started using boats, they were not travelling alone. Since $1800 \mathrm{AD}$ an incessant increase in the annual rate of biota introductions has been observed in Europe (Hulme 2009). In temperate regions such as the European Atlantic coasts, shipping is the main pathway for the introduction of exotics (Molnar et al. 2008; Nunes et al. 2014). Consequently, commercial ports with intense maritime traffic have become 'alien hotspots'.

The early detection of alien or non-indigenous species (NIS) and the identification of invasion vectors are crucial to prevent further introductions (Nunes et al. 2014). Invaders may remain unnoticed for a long time when they are morphologically similar to other co-occurring species (e.g. Grosholz 2002; FernándezÁlvarez \& Machordom 2013). DNA barcoding techniques can be useful for species identification when morphological taxonomic assignment is difficult. The successful application of this approach requires, as a minimum: (a) primers that anneal in the target region of the problem species, and (b) pedigreed reference sequences of that DNA region and species (i.e. DNA barcodes) available in accessible databases for comparison. This means sequences from specimens identified by taxonomic specialists, and with a voucher specimen in accessible museum collections (Crocetta et al. 2015).

According to Molnar et al. (2008), the molluscs contain the highest number of invasive species with high ecological impact. For example, the Pacific oyster Crassostrea gigas (Thunberg, 1793) has been introduced into 45 ecoregions (Molnar et al. 2008), mostly intentionally as a commercial species. It has been reported in the centre of the Bay of Biscay, where the problem of invasive molluscs has been recognized on a regional scale (Arias \& Anadón 2012, 2013).

The present study is focused on exotic and cryptogenic mollusc species associated with maritime ports of the central area of the Bay of Biscay in northern Iberia (Asturias region). In this region, mussel communities are dominated by the native Mytilus galloprovincialis Lamarck, 1819, a species of enormous phenotypic plasticity that is often confused with other mussel species (e.g. Geller 1999). The departure hypothesis was that the molecular approach of the present work 
would allow detection of exotic molluscs that may be overlooked de visu in routine monitoring. Genetic barcodes were obtained using universal primers and compared against public DNA data sets (GenBank) for species identification/confirmation. Furthermore, deep taxonomic morphological analysis was done in order to confirm molecular species identification.

\section{Materials and methods}

\section{Study area with environmental conditions and sampling design}

This study was conducted across the central coasts of the Asturias region, northern Iberia, Bay of Biscay. The temperate Cantabric coastline of the study area is approximately $70 \mathrm{~km}$ long with a heterogeneous intertidal environment. It is dominated by a rocky uplifted morphology (cliffs) and rocky shores with several small sandy beaches and a few estuaries. It contains two international trade ports under state control (Avilés and Gijón - El Musel) and 24 small regional ports with an average surface area of $31,900 \mathrm{~m}^{2}$ (Flor et al. 2006).

Molluscs were collected during the low tide from three ports with different intensities of maritime traffic: Avilés, Gijón and Luanco (Table I). Inside the ports, sampling was done from artificial structures as well as from natural rocks closest to the port's artificial substrate. The sampling protocol was modified from the Rapid Survey described by Minchin (2007): targeting molluscs (i.e. ignoring the rest of the biota); including rocks; setting a sampling area per location for comparable sampling effort despite very different port sizes. The surface sampled from each location (artificial or natural substrate) was approximately $200 \mathrm{~m}^{2}$. For representative sampling, molluscs were randomly collected from the total surface with a sampling effort of roughly $1 / 100$ visually detected individuals. In order to avoid biases due to patchy spatial distributions, before starting sampling we made a previous visual inspection to determine the morphotypes present in the sampling site. Then we tried to collect a number of individuals of each morphotype proportional to the abundance of the morphotype.
For the samples to be comparable, sampling was limited to areas similar in terms of wave exposure (ports are sheltered areas) and algae coverage (uncovered areas), because these are the main natural factors that shape intertidal marine communities (Underwood \& Denley 1984). The Avilés port is located within the estuary of the River Avilés, a small stream of fluvial discharge with irregular flow (Flor et al. 2006).

The mollusc specimens were taken to the laboratory. For each morphological type one voucher specimen was photographed and the whole organism preserved in $96 \%$ ethanol. The rest of the individuals collected were also preserved in $96 \%$ ethanol for further DNA extraction. All vouchers and tissue samples have been lodged in the Department of Functional Biology, University of Oviedo.

\section{Molecular species identification}

A molecular taxonomy approach was used for identification of molluscs to the species level. Two mitochondrial genes were employed: cytochrome c oxidase subunit I (COI) and 16S ribosomal RNA (rRNA) genes. An additional nuclear locus (Glu $5^{\prime}$ ) was employed for discrimination between the genetically close species of the Mytilus edulis complex (M. edulis Linnaeus, 1758, M. galloprovincialis and M. trossulus Gould, 1850). Hybrids of $M$. edulis and $M$. galloprovincialis occur in this region (Crego-Prieto et al. 2014). Furthermore, recombination of Mytilus mtDNA (Ladoukakis \& Zouros 2001), and double uniparental inheritance of mitochondrial DNA in bivalves (e.g. Passamonti \& Scali 2001; Plazzi et al. 2015) could complicate species assignment using mitochondrial loci.

DNA extraction was based on Chelex (Bio-Rad) resin from the mollusc's foot muscle tissue. The EZNA Mollusc DNA Kit (Omega Bio-Tek Inc.), following the manufacturer's instructions, was applied when the former procedure failed to extract good quality DNA (checked on $1.5 \%$ agarose gels stained with ethidium bromide).

For the COI gene, amplification of DNA templates was performed with the primers described by Geller et al. (2013). Polymerase chain reaction (PCR) mixes were done in the final volume of $43 \mu$ l containing $1 \times$

Table I. Description of the main environmental characteristics of the sampling sites.

\begin{tabular}{lcccccccc}
\hline Location & Site & Latitude & Longitude & $N$ & $\begin{array}{c}\text { Freshwater } \\
\text { discharge }\end{array}$ & $\begin{array}{c}\text { Thermal } \\
\text { discharge }\end{array}$ & Maritime traffic & Water quality status \\
\hline Avilés & Port - estuary & $43^{\circ} 33^{\prime} 49^{\prime \prime} \mathrm{N}$ & $5^{\circ} 55^{\prime} 18^{\prime \prime} \mathrm{W}$ & 167 & Yes & Yes & 5.12 & Heavily modified water body (WFD) \\
Gijón & Port - bay & $43^{\circ} 32^{\prime} 49^{\prime \prime} \mathrm{N}$ & $5^{\circ} 40^{\prime} 05^{\prime \prime} \mathrm{W}$ & 193 & No & No & 17.23 & Heavily modified water body (WFD) \\
Luanco & Port - bay & $43^{\circ} 36^{\prime} 57^{\prime \prime} \mathrm{N}$ & $5^{\circ} 47^{\prime} 21^{\prime \prime} \mathrm{W}$ & 146 & No & No & $2.36 \times 10^{-5}$ & Blue Flag (FEE) \\
\hline
\end{tabular}

Note: Maritime traffic, annual marine traffic in million tons for 2012 . $N$, sample size. 
Taq buffer, $3.5 \mathrm{mM} \mathrm{MgCl}, 0.5 \mathrm{mM}$ dNTPs, $0.2 \mu \mathrm{M}$ of each primer, $1.5 \mathrm{U}$ Taq polymerase (Promega) and 50 ng of isolated DNA. PCR amplification was performed in a Verti Blue Thermal Cycler, Applied Biosystems, with an initial denaturation at $95^{\circ} \mathrm{C}$ for $5 \mathrm{~min}$; then 35 cycles of denaturation of $1 \mathrm{~min}$ at $95^{\circ} \mathrm{C}$, annealing at $48^{\circ} \mathrm{C}$ for $1 \mathrm{~min}$, extension at $72^{\circ} \mathrm{C}$ for $1 \mathrm{~min}$ and a final extension at $72^{\circ} \mathrm{C}$ for $5 \mathrm{~min}$.

Amplification of a fragment of the mitochondrial 16S rRNA gene was done using the primers described by Palumbi et al. (1991), with the final volume of 20 $\mu$ l containing $1 \times$ Taq buffer, $2.5 \mathrm{mM} \mathrm{MgCl}, 0.25 \mathrm{mM}$ dNTPs, $1 \mu \mathrm{M}$ of each primer, $1.5 \mathrm{U}$ Taq polymerase (Promega), and $2 \mu \mathrm{l}$ of isolated DNA. PCR conditions were an initial denaturation at $95^{\circ} \mathrm{C}$ for $5 \mathrm{~min}$; then 30 cycles of denaturation at $94^{\circ} \mathrm{C}$ for $1 \mathrm{~min}$, annealing at $55^{\circ} \mathrm{C}$ for $1 \mathrm{~min}$; extension at $72^{\circ} \mathrm{C}$ for $2 \mathrm{~min}$ and a final extension at $72^{\circ} \mathrm{C}$ for $7 \mathrm{~min}$.

PCR products were run on $2 \%$ agarose gels stained with ethidium bromide. The amplified fragment (always of the expected size for each gene, i.e. approx. 460 and 630 base pairs for $16 \mathrm{~S}$ rRNA and COI gene, respectively) was excised from the gel and purified with a Purification Kit (GE Healthcare) following the manufacturer's instructions. PCR products were sequenced by ABI PRISM 3130 Genetic Analyzer (Applied Biosystems) using the BigDye 3.1 Terminator system at the Unit of Genetic Analysis at the University of Oviedo. Sequences were edited with SeqMan (DNASTAR, Inc.).

The locus Glu 5' encodes the polyphenolic adhesive protein in Mytilus spp. (Rawson et al. 1996) and provides species-specific products after PCR: one or two fragments $350 / 380$ base pairs (bp) long correspond to $M$. edulis, one $240 \mathrm{bp}$ long fragment to M. trossulus, and one or two fragments of 200/300/ $500 \mathrm{bp}$ to M. galloprovincialis. Amplification was performed with the primers $\mathrm{JH}-5$ and $\mathrm{JH}-54$ described by Rawson et al. (1996) and the conditions described therein. Amplified products were directly resolved in a $3 \%$ agarose gel stained with ethidium bromide and compared with a GeneRuler 100 bp DNA Ladder (Thermo Scientific).

\section{Species assignation based on DNA sequences}

The quality of sequences was first examined by directly checking the electropherograms. The BLASTn tool was used for the pairwise alignment of the sequences with the closest matches in GenBank and confirmed the absence of big insertions, deletions and inversions. In addition, $\mathrm{CO}$ sequences were checked for putative proteins with the software ExPASy to confirm they did not contain nonsense substitutions or stop codons.
For species identification, sequences were compared with online databases using BLASTn within the NCBI Nucleotide database and BOLD database Species Level Barcode Records within the BOLD Identification System. Species identification was made based on the closest match (minimum 99\% sequence identity in all cases).

COI and 16S rRNA haplotypes per species were determined based on DNA sequence variation (singlenucleotide polymorphisms, SNPs).

\section{Species assignation based on phylogenetic tree}

Sequences identifying the exotic molluscs (Xenostrobus securis (Lamarck, 1819), Mytilaster minimus (Poll, 1795), Crassostrea gigas (Thunberg, 1793) and Ostrea stentina Payraudeau, 1826) from BLAST-based methodology were aligned together with reference sequences of different molluscs from the same families (Mytilidae and Ostreidae) using the BioEdit program (Hall 1999).

Phylogenetic analyses were conducted using MEGA version 6 (Tamura et al. 2013). This software was used to construct the phylogenetic tree based on aligned sequences. A phylogenetic tree containing the reference and the exotic mollusc sequences was reconstructed by the method of Neighbour-Joining with the following settings: Tamura Nei model (Tamura \& Nei 1993) and uniform rates. This is the standard method of phylogenetic inference in DNA barcoding studies (Hebert et al. 2003); robustness of the Neighbour-Joining topology was assessed using 1000 bootstrap replicates.

\section{Taxonomic confirmation of species status based on diagnostic morphological traits}

For confirmation of genetic species assignation, we performed a deep analysis of the diagnostic morphological features of the studied mollusc species. It was based mainly on shell characteristics, i.e. shell shape and its external (growth lines, lamellae and ribs, umbo position and shape, etc.) and inner (pallial sinus, muscle scar shape and position) surfaces; shell colour; hinge type, etc.

\section{Taxonomical and biological references}

The nomenclature and the species taxonomical status is consistent with the World Register of Marine Species (WoRMS), accessed in March 2015. The terminology for the invasive status of the species follows the Invasive Species Specialist Group (ISSG) of the International Union for Conservation of Nature (IUCN). The 
ISSG global invasive database is available online (accessed September 2015).

\section{Results}

A total of 506 mollusc individuals were collected from the three ports, belonging to 18 unambiguously morphologically and genetically identified species (Table II). Of these, 25 individuals corresponded to one cryptogenic and three NIS of bivalves. Only one of them, Crassostrea gigas, has previously been reported in Asturias (Arias et al. 2012). The dwarf oyster Ostrea stentina and the Australian pygmy mussel Xenostrobus securis are reported for the first time in the Asturian region. Furthermore, the finding of $O$. stentina represents its first record in the Bay of Biscay and its northernmost distribution to date. Regarding the cryptogenic species sensu Carlton (1996) we found a mussel species, Mytilaster minimus, that fits this category. Crassostrea gigas and $X$. securis are recognized as invasive species by the ISSG.

Sequences of the expected sizes (460 and 630 for $16 \mathrm{~S}$ rRNA and COI genes, respectively) were recovered from all individuals for the 16S rRNA gene. In total we recovered one $16 \mathrm{~S}$ rRNA gene haplotype for each C. gigas, $O$. stentina and $X$. securis, and three haplotypes from $M$. minimus. For the COI gene we recovered two, three and one haplotypes for $C$. gigas, $O$. stentina and $X$. securis, respectively. COI gene amplification was not possible for $M$. minimus with the primers employed. The haplotypes are accessible in GenBank with the accession numbers KJ818207-KJ818240 and KJ865878-KJ865879 (Table III). The 16S rRNA gene sequences obtained for $C$. gigas, $M$. minimus and O. stentina were assigned with $99 \%$ or higher identity to reference species in GenBank, while the 16S rRNA gene haplotype obtained for $X$. securis did not reach the identity threshold of $99 \%$ (Table IV). The COI gene haplotypes retrieved were in all cases a highly significant match with reference sequences, also at the $99 \%$ threshold, in both the GenBank and BOLD databases. From the information recovered from the databases, voucher specimens were available only for $X$. securis and $C$. gigas (Table IV). However, the taxonomic status of the putative NIS was fully confirmed from morphological analysis and diagnostic criteria. Crassostrea gigas is relatively easy to differentiate from the native oysters on the basis of shell morphology and muscular scars, the same occurring with $X$. securis and the indigenous mussels. Nevertheless, the morphological identification of $O$. stentina is somewhat more complicated, because the species is morphologically similar to O. edulis. In this case we paid special attention to the following four characters: (i) the relationship between the height and width of the shell; (ii) the shape and position of the umbo (= beak) of the shell; (iii) the crenulations of the anterior-dorsal and postero-dorsal edges of the shell; and (iv) the maximum size of the specimens. Examined specimens of $O$. stentina had shells higher than wide, maximum size $40 \mathrm{~mm}$ (almost equal in 0 . edulis, more or less rounded shape with a maximum size of $100 \mathrm{~mm}$ ); umbones turned on the side and directed posteriorly - opisthogyrous - (nearly orthogyrous in O. edulis) and with very conspicuous crenulations near the umbo (in O. edulis the crenulations are little marked).

The 25 NIS-cryptogenic individuals found in this survey represented $4.9 \%$ of the total sample. Their frequency was higher than $12 \%$ of the total number of Mollusca collected in samples from the port located in an

Table II. Distribution of the mollusc species sampled from each port, in percentage (absolute number in parentheses).

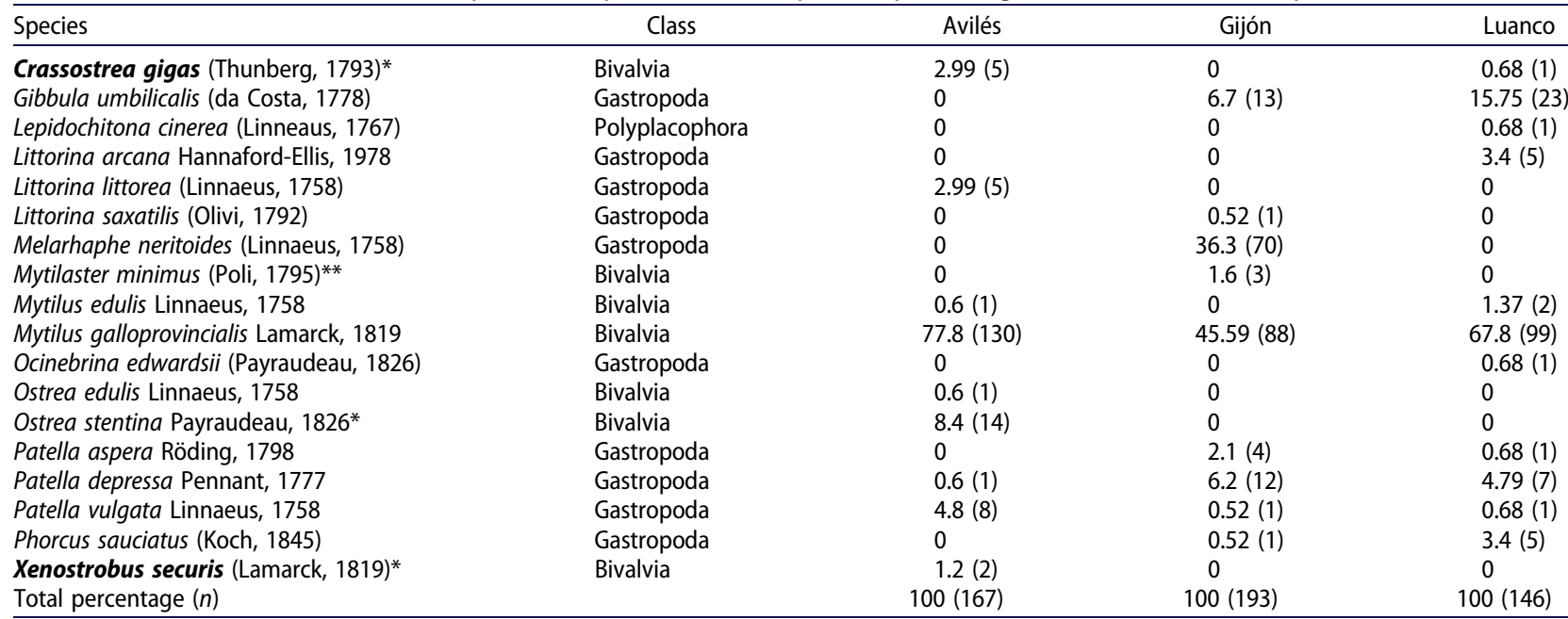

Note: Non-native and cryptogenic species are marked with one and two asterisks, respectively. Invasive species in bold. 
Table III. NIS/cryptogenic species found in the ports studied.

\begin{tabular}{|c|c|c|c|c|c|c|c|}
\hline \multirow{2}{*}{$\begin{array}{l}\text { Exotic } \\
\text { mollusc }\end{array}$} & \multicolumn{4}{|c|}{ Geographic } & \multicolumn{3}{|c|}{ 16S rRNA } \\
\hline & Native range & extent & Closer record & Status & $N$ & AN & COI AN \\
\hline $\begin{array}{l}\text { Crassostrea } \\
\text { gigas }\end{array}$ & $\begin{array}{l}\text { Japan and southwest Asia coasts (http:// } \\
\text { www.marinespecies.org/aphia.php?p= } \\
\text { taxdetails\&id=140656) }\end{array}$ & $\begin{array}{l}\text { Multi-ecoregions } \\
\text { (Molnar et al. } \\
\text { 2008) }\end{array}$ & $\begin{array}{l}\text { Eo estuary }(100 \mathrm{~km} \\
\text { west; Semeraro et al. } \\
\text { 2015) }\end{array}$ & Invasive & $6(1.18 \%)$ & KJ818214 & $\begin{array}{l}\text { KJ818236 } \\
\text { KJ818240 }\end{array}$ \\
\hline $\begin{array}{l}\text { Ostrea } \\
\text { stentina }\end{array}$ & $\begin{array}{l}\text { Southern Mediterranean coasts, African } \\
\text { Atlantic coasts; historical presence: } \\
\text { southwestern coast of the Iberian Peninsula } \\
\text { (Lapegue et al. 2006) }\end{array}$ & Unknown & $\begin{array}{l}\text { Sado estuary ( } 800 \\
\text { km southwest; } \\
\text { Lapegue et al. 2006) }\end{array}$ & $\begin{array}{l}\text { Not } \\
\text { evaluated }\end{array}$ & $14(2.77 \%)$ & KJ818210 & $\begin{array}{l}\text { KJ818237 } \\
\text { KJ818238 } \\
\text { KJ818239 }\end{array}$ \\
\hline $\begin{array}{l}\text { Mytilaster } \\
\text { minimus }\end{array}$ & $\begin{array}{l}\text { Mediterranean Sea and neighbouring } \\
\text { Atlantic (Poppe \& Goto 2000). }\end{array}$ & Unknown & $\begin{array}{l}\text { Colunga cove ( } 32 \mathrm{~km} \\
\text { east; Ortea 1974) }\end{array}$ & $\begin{array}{l}\text { Not } \\
\text { evaluated }\end{array}$ & $3(0.59 \%)$ & $\begin{array}{l}\text { KJ818208 } \\
\text { KJ818209 } \\
\text { KJ818212 }\end{array}$ & $n / a$ \\
\hline $\begin{array}{l}\text { Xenostrobus } \\
\text { securis }\end{array}$ & $\begin{array}{l}\text { New Zealand and Australian coasts (http:// } \\
\text { www.marinespecies.org/aphia.php?p= } \\
\text { taxdetails\&id=140485) }\end{array}$ & $\begin{array}{l}\text { Multi-ecoregion } \\
\text { (http://www. } \\
\text { ciesm.org) }\end{array}$ & $\begin{array}{l}\text { Basque Country ( } 350 \\
\text { km east) }\end{array}$ & Invasive & $2(0.39 \%)$ & KJ818207 & KJ818225 \\
\hline & & & & TOTAL & 25 (4.94\%) & & \\
\hline
\end{tabular}

Note: Native distribution area; species status from the International Union for Conservation of Nature (IUCN); number (\%) of individuals of each species. AN GenBank accession numbers of the haplotypes found in this study for each species and gene (16 rRNA and COI).

estuary (Avilés; see Table II): 21 NIS versus 146 natives. The difference in the distribution of NIS and native individuals between Avilés and the other two ports (three NIS versus 190 natives and one NIS versus 145 natives for Gijón and Luanco, respectively) was statistically significant (Chi-square $=17.92,2$ degrees of freedom, $P<$ 0.001). The NIS native range for $C$. gigas is the Pacific Ocean, the South Pacific for $X$. securis and the Mediterranean Sea and other eastern areas of the Atlantic Ocean for O. stentina, including African waters (Table III). The dwarf oyster (or Provence flat oyster), formerly named in the literature as O. stentina or O. aupouria Dinamani, 1981 , has never been reported in northern Iberia until now. Moreover, this is the first record of this species outside its native range. Both the $16 \mathrm{~S}$ and COI haplotypes found in our study clustered with the GenBank references (DQ313180 and DQ313183, respectively) of O. stentina (Table IV) sampled from a small area, the Dakhla Bay, in Morocco (Lapegue et al. 2006). The COI haplotype of $X$. securis (KJ818225) found in Avilés clustered with a genetic lineage of the species found in
Australia (Reference KC509698 with voucher specimen; Table IV). For C. gigas the haplotype found in Asturias ports clustered with samples from different continents. The closest match corresponded to a Brazilian voucher specimen for the $\mathrm{COI}$ gene and a Chinese voucher for the 16S rRNA gene (Table IV). For M. minimus only one $16 \mathrm{~S}$ rRNA reference sequence (from the Mediterranean Sea) could be found in GenBank (Table IV), which exhibited $99 \%$ identity with the sequences obtained in this study and had no voucher specimen. Few references with $>97 \%$ identity with the sequences found in this study were found for $M$. minimus, O. stentina (the two genes) and 16S rRNA for $X$. securis (Table IV).

The sequences generated in this study do in fact group with sequences from the same species. Familyspecific trees were reconstructed from the $16 \mathrm{~S}$ rRNA gene sequences obtained in this study and references from GenBank with voucher specimens. The phylogenetic proximity of the new sequences and database references was confirmed for both Mytilidae (Figure 1a) and Ostreidae (Figure 1b). Regarding

Table IV. Reference sequences available in GenBank for the NIS and cryptogenic species found in the present study.

\begin{tabular}{|c|c|c|c|c|c|c|c|c|}
\hline Species & Gene & $\begin{array}{c}\text { Accession } \\
\text { number }\end{array}$ & Score & $\begin{array}{c}\text { Coverage } \\
(\%)\end{array}$ & $\begin{array}{l}\text { Identity } \\
(\%)\end{array}$ & $\begin{array}{l}\text { Geographical } \\
\text { regions }\end{array}$ & $\begin{array}{l}\text { Voucher } \\
\text { specimens }\end{array}$ & $\begin{array}{c}\text { Number of sequences with } \\
>97 \% \text { identity }\end{array}$ \\
\hline \multirow[t]{2}{*}{ Crassostrea gigas } & $\begin{array}{c}16 S \\
\text { rRNA }\end{array}$ & KJ855245 & 797 & 100 & 100 & China & Yes & 39 \\
\hline & $\mathrm{COI}$ & JF717608 & 1179 & 100 & 100 & Brazil & Yes & $>50$ \\
\hline $\begin{array}{l}\text { Mytilaster } \\
\text { minimus }\end{array}$ & $\begin{array}{l}16 S \\
\text { rRNA }\end{array}$ & DQ836017 & 780 & 100 & 99 & Mediterranean Sea & $\mathrm{n} / \mathrm{a}$ & 1 \\
\hline \multirow[t]{2}{*}{ Ostrea stentina* } & $\begin{array}{c}16 S \\
\text { rRNA }\end{array}$ & DQ313180 & 741 & 93 & 100 & Morocco & $\mathrm{n} / \mathrm{a}$ & 2 \\
\hline & $\mathrm{COI}$ & DQ313183 & 950 & 81 & 100 & Morocco & $\mathrm{n} / \mathrm{a}$ & 2 \\
\hline \multirow[t]{2}{*}{$\begin{array}{l}\text { Xenostrobus } \\
\text { securis* }\end{array}$} & $\begin{array}{c}16 S \\
\text { rRNA }\end{array}$ & AB372227 & 630 & 97 & 94 & Japan & $\mathrm{n} / \mathrm{a}$ & 0 \\
\hline & $\mathrm{COI}$ & KC509698 & 1107 & 100 & 99 & Australia & Yes & 20 \\
\hline
\end{tabular}

Note: For the best match reference: accession number; hit score, coverage and identity retrieved by BLAST; geographic origin (if available); availability of voucher specimen. Number of GenBank sequences with $>97 \%$ identity with the sequence obtained in this study, all of them of the target species. n/a, not available.

*Ostreola stentina and Limnoperna securis were renamed as Ostrea stentina and Xenostrobus securis, respectively, following current nomenclature in the World Register of Marine Species (WoRMS Editorial Board 2014), available online at http://www.marinespecies.org/ (accessed July 2015). 


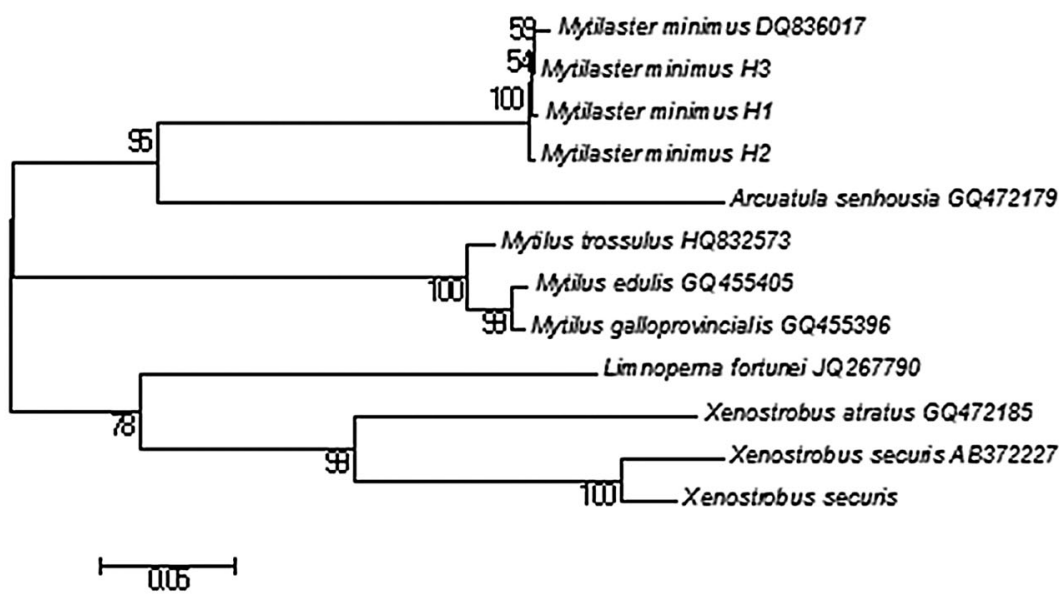

B Ostrea edulis JF808187

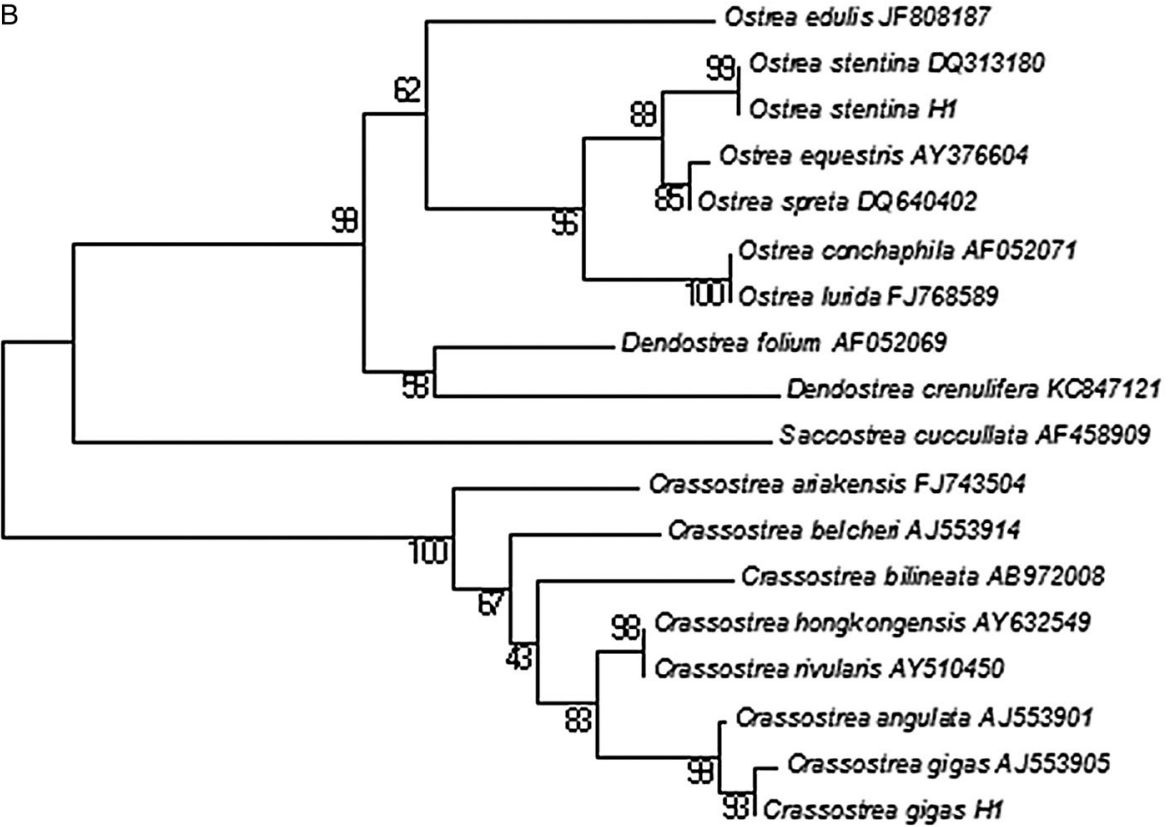

एवा -1

Figure 1. Neighbour-Joining trees reconstructed from GenBank reference sequences and the 16S rDNA haplotypes obtained in this study for the family Mytilidae ( $A$, above) and Ostreidae ( $B$, below). The references are identified by their accession number.

natives, 14 species were found (Table II): one chiton (Polyplacophora), three bivalves and 10 gastropods. The Mediterranean mussel $M$. galloprovincialis was the dominant species in the three ports (Table II). A few Mytilus edulis specimens were found in Avilés and Luanco, but no interspecific hybrids. The next species in abundance were the small periwinkle Melarhaphe neritoides (Linnaeus, 1758) in Gijon, the topshell Gibbula umbilicalis (da Costa, 1778) in Luanco, and the limpet Patella vulgata Linnaeus, 1758 in Avilés. The native:NIS species ratio was 6:3, 8:1 and 10:1 for Avilés, Gijón and Luanco ports, respectively. The proportion of bivalves for the same ports was, respectively, $91.6 \%, 47.2 \%$ and $69.9 \%$, not correlated with the respective NIS abundance.

\section{Discussion}

In this study, alien molluscs were found associated with ports in the central Cantabrian Sea (northern Spain). The higher frequency of NIS in samples from the port located in an estuary (Avilés) could be explained by low salinity, favourable for the settlement of exotics (Wolff 1999; Paavola et al. 2005), and warmer temperatures in the inner estuary (García et al. 2009) that could potentially promote the establishment of subtropicalmeridional exotic species, in this case the oyster Ostrea stentina. Although the port of Gijón has triple the frequency of marine traffic (expressed in cargo tonnage), the other stressors could explain a higher proportion of non-native molluscs in Avilés estuary. 
Two NIS detected here, Xenostrobus securis and O. stentina, have not been reported in the Asturian region until now. Moreover, for $O$. stentina this is the first validated record out of their native range. One reason could be that they can be cryptic when other oysters are in the same environment. Without using molecular taxonomy methodology, it is possible that the newly reported exotics found here would remain undetected, at least for some time. Ostrea edulis and $O$. stentina are members of the same genus and share a number of characters, being hard to distinguish morphologically at first glance. Although a detailed taxonomical examination is needed for its accurate identification, they exhibit notable genetic differences (Lapegue et al. 2006), also confirmed from the phylogenetic trees (Figure 1). In other studies some $O$. stentina specimens could not be distinguished from $C$. gigas based on external shell morphology alone (Dridi et al. 2008). Therefore, the presence of $O$. stentina in our study area could most likely remain undetected without the use of genetic markers. DNA barcoding techniques have also been useful for mussel identification in our study. The Australian pygmy mussel (X. securis) has already been introduced in other parts of North Iberia, i.e. some Galician estuaries (Pascual et al. 2010) and the Nervión estuary in the Basque Country (Adarraga \& Martínez 2012). Therefore, the presence of this mussel in a region located between those areas is not surprising due to its invasive potential (Gestoso et al. 2012). On the other hand, Mytilaster minimus has had a controversial taxonomic history due to many synonymies and subspecies or variants (e.g. Ortea 1974; Poppe \& Goto 2000). Furthermore, the species is similar to juveniles of Mytilus, which may cause confusion between both species (Gofas et al. 2011). This may in turn lead to misidentifications of the species and suggests that some of its previous records could be equivocal. Although the results of this study have only a regional and therefore limited dimension, it is clear that genetic tools overcome mollusc biodiversity underestimations, discovering a set of cryptic alien bivalves. The importance of the application of DNA barcoding for biosecurity is well recognized (Valentini et al. 2008). Based on our modest but significant results, monitoring of molluscs deserves particular attention when identification comes to the species level.

For the objective of the present study, that is the recognition of non-native species, DNA analysis is relatively fast and cheap. DNA extraction, PCR and sequencing costs are reasonable now, and can be reduced if the process is automated. In the present study the cost per sample for the two mitochondrial genes employed was approximately $€ 10$ (excluding salary). The whole process of DNA extraction, PCR and sequencing of the samples from each port was shorter than 48 hours. Indeed, morphological examination has no cost for materials and analysis, but is laborious and requires taxonomic expertise that according to different authors has been declining worldwide over recent decades (Hopkins \& Freckleton 2002; Kim \& Byrne 2006). However, one weakness of DNA barcoding is the lack of voucher specimens for many reference sequences found in databases (e.g. Crocetta et al. 2015), and from the present study we confirm that this is a problem. Two of the NIS-cryptogenic species found in our study had no voucher specimens for DNA references when we consulted the databases in July 2015. Incorporating vouchers in the current databases will considerably improve the value and utility of DNA barcoding for routine monitoring.

In conclusion, using DNA barcoding and deep morphological examination on molluscs sampled with a modified Rapid Survey protocol led to the detection of new unknown NIS in the region. This highlights the usefulness of combining the two methods when morphological plasticity of natives and/or exotics occurs, or when paucity of pedigreed reference sequences in the public datasets exists. This type of assessment could help in the future with biosecurity analysis and port surveys.

\section{Acknowledgements}

Ivana Pejovic expresses gratitude to the International Masters in Marine Biodiversity and Conservation Consortium for granting the Erasmus Mundus scholarship. We are grateful to Anastasija Zaiko for her participation in field sampling and critical reading of the initial manuscript.

\section{Disclosure statement}

No potential conflict of interest was reported by the authors.

\section{Funding}

This work was supported by the Spanish National Ministry of Economy and Competitiveness under Grant MINECO CGL2013-42415-R and the Principality of Asturias under Grants GRUPIN14-093 and UNOV-13-EMERG-05. Laura Miralles was supported by the Asturias Regional Government under PCTI Grant BP 10-004. Alba Ardura holds a post-doctoral fellowship Clarin-COFUND-PCTI-FICYT.

\section{ORCID}

Andres Arias (1) http://orcid.org/0000-0002-1364-7204 


\section{References}

Adarraga I, Martínez J. 2012. First record of the invasive brackish water mytilid Limnoperna securis (Lamarck, 1819) in the Bay of Biscay. Aquatic Invasions 7(2):171-80. doi:10.3391/ ai.2012.7.2.003

Arias A, Anadón N. 2012. First record of Mercenaria mercenaria (Bivalvia: Veneridae) and Ensis directus (Bivalvia: Pharidae) on Bay of Biscay, Iberian Peninsula. Journal of Shellfish Research 31:57-60. doi:10.2983/035.031.0107

Arias A, Anadón N. 2013. Tonicia atrata and Chiton cumingsii (Polyplacophora: Chitonidae): first records in European waters. Zootaxa 3626(4):593-96. doi:10.11646/zootaxa. 3626.4.14

Arias A, Richter A, Anadón N. 2012. Estado actual de los moluscos marinos no autóctonos en aguas del Cantábrico. In: GEIB Grupo Especialista en Invasiones Biológicas, editors. EEl 2012 Notas Científicas, p 99-103. $4^{\circ}$ Congreso Nacional sobre Especies Exóticas Invasoras 'EEI 2012'. GEIB, Serie Técnica N 5. León, Spain.

Crego-Prieto V, Arrojo-Fernández J, Prado A, MachadoSchiaffino G, Izquierdo Jl, Roca A, et al. 2014. Cytological and population genetic changes in Northwestern Iberian mussels after the Prestige oil spill. Estuaries and Coasts 37:995-1003. doi:10.1007/s12237-013-9738-5

Crocetta F, Mariottini P, Salvi D, Oliverio M. 2015. Does GenBank provide a reliable DNA barcode reference to identify small alien oysters invading the Mediterranean Sea? Journal of the Marine Biological Association of the United Kingdom 95:111-22. doi:10.1017/S0025315414001 027

Dridi S, Romdhane MS, Heurtebise S, Cafsi EM, Boudry P, Lapegue S. 2008. Genetic characterisation of oyster populations along the north-eastern coast of Tunisia. African Journal of Marine Science 30(3):489-95. doi:10.2989/ AJMS.2008.30.3.4.638

Fernández-Álvarez FA, Machordom A. 2013. DNA barcoding reveals a cryptic nemertean invasion in Atlantic and Mediterranean waters. Helgoland Marine Research 67:599-605. doi:10.1007/s10152-013-0346-3

Flor G, del Busto JA, Flor Blanco G. 2006. Morphological and sedimentary patterns of ports of the Asturian Region (NW Spain). Journal of Coastal Research 48:35-40.

García P, Zapico E, Colubi A. 2009. An angiosperm quality index (AQI) for Cantabrian estuaries. Ecological Indicators 9(5):856-65. doi:10.1016/j.ecolind.2008.10.002

Geller JB. 1999. Decline of native species masked by sibling species invasion: the case of Californian marine mussels. Conservation Biology 13:661-64. doi:10.1046/j.1523-1739. 1999.97470.x

Geller J, Meyer C, Parker M, Hawk H. 2013. Redesign of PCR primers for mitochondrial cytochrome $\mathrm{c}$ oxidase subunit I for marine invertebrates and application in all-taxa biotic surveys. Molecular Ecology Resources 13(5):851-61. doi:10.1111/1755-0998.12138

Gestoso I, Olabarria C, Arenas F. 2012. The invasive mussel Xenostrobus securis along the Galician Rias Baixas (NW of Spain): status of invasion. Cahiers de Biologie Marine 53 (3):391-96.

Gofas S, Moreno D, Salas C. 2011. Moluscos Marinos de Andalucía: I y II. Clase Gastropoda (Heterobranchia), Clase Bivalvia, Clase Scaphopoda, Clase Cephalopoda, Glosario e
Índices. Málaga: Servicio de Publicaciones e Intercambio Científico, Universidad de Málaga, p 343-798.

Grosholz E. 2002. Ecological and evolutionary consequences of coastal invasions. Trends in Ecology and Evolution 17 (1):22-27. doi:10.1016/S0169-5347(01)02358-8

Hall A. 1999. BioEdit: a user-friendly biological sequence alignment editor and analysis program for Windows 95/98/NT. Nucleic Acids, Symposium Series 41:95-98.

Hebert P, Cywinska A, Ball S, deWaard J. 2003. Biological identification through DNA barcodes. Proceedings of the Royal Society B 270:313-21. doi:10.1098/rspb.2002.2218

Hopkins GW, Freckleton RP. 2002. Declines in the numbers of amateur and professional taxonomists: implications for conservation. Animal Conservation 5:245-49. doi:10.1017/ S1367943002002299

Hulme PE. 2009. Trade, transport and trouble: managing invasive species pathways in an era of globalization. Journal of Applied Ecology 46:10-18. doi:10.1111/j.1365-2664.2008. 01600.x

Kim KC, Byrne LB. 2006. Biodiversity loss and the taxonomic bottleneck: emerging biodiversity science. Ecological Research 21:794-810. doi:10.1007/s11284-006-0035-7

Ladoukakis ED, Zouros E. 2001. Direct evidence for homologous recombination in mussel (Mytilus galloprovincialis) mitocondrial DNA. Molecular Biology and Evolution 18:1168-75. doi:10.1093/oxfordjournals.molbev.a003904

Lapègue S, Ben Salah I, Batista FM, Heurtebise S, Neifar L, Boudry P. 2006. Phylogeographic study of the dwarf oyster, Ostreola stentina, from Morocco, Portugal and Tunisia: evidence of a geographic disjunction with the closely related taxa, Ostrea aupouria and Ostreola equestris. Marine Biology 150:103-10. doi:10.1007/s00227006-0333-1

Minchin D. 2007. Rapid coastal survey for targeted alien species associated with floating pontoons in Ireland. Aquatic Invasions 2(1):63-70. doi:10.3391/ai.2007.2.1.8

Molnar JL, Gamboa RL, Revenga C, Spalding MD. 2008. Assessing the global threat of invasive species to marine biodiversity. Frontiers in Ecology and the Environment 6:485-92. doi:10.1890/070064

Nunes AL, Katsanevakis S, Zenetos A, Cardoso AC. 2014. Gateways to alien invasions in the European seas. Aquatic Invasions 9:133-44. doi:10.3391/ai.2014.9.2.02

Ortea JA. 1974. Moluscos marinos gasterópodos y bivalvos del litoral asturiano entre Ribadesella y Ribadeo, con especial atención a la subclase Opistobranquia. Tomo I. Doctoral Thesis, Universidad de Oviedo. 342 pages.

Paavola M, Olenin S, Leppakoski E. 2005. Are invasive species most successful in habitats of low native species richness across European brackish water seas? Estuarine, Coastal and Shelf Science 64:738-50. doi:10.1016/j.ecss. 2005.03.021

Palumbi S, Martin A, Romano S, McMillan WO, Stice L, Grabowski G. 1991. The Simple Fool's Guide to PCR. Version 2. Honululu: University of Hawaii. 42 pages.

Pascual S, Villalba A, Abollo E, Garci M, González AF, Nombela $M$, et al. 2010. The mussel Xenostrobus securis: a well-established alien invader in the Ria de Vigo (Spain, NE Atlantic). Biological Invasions 12(7):2091-103. doi:10.1007/s10530009-9611-4

Passamonti M, Scali V. 2001. Gender-associated mitochondrial DNA heteroplasmy in the venerid clam Tapes philippinarum 
(Mollusca Bivalvia). Current Genetics 39(2):117-24. doi:10. 1007/s002940100188

Plazzi F, Cassano A, Passamonti M. 2015. The quest for doubly uniparental inheritance in heterodont bivalves and its detection in Meretrix lamarckii (Veneridae: Meretricinae). Journal of Zoological Systematics and Evolutionary Research 53(1):87-94. doi:10.1111/jzs.12078

Poppe GT, Goto Y. 2000. European Seashells. Vol. II, 2nd edition. Hackenheim: ConchBooks. 221 pages.

Rawson PD, Joyner KL, Meetze K, Hilbish TJ. 1996. Evidence for intragenic recombination within a novel genetic marker that distinguishes mussels in the Mytilus edulis species complex. Heredity 77(6):599-607. doi:10.1038/hdy.1996.187

Semeraro A, Mohammed-Geba K, Arias A, Anadón N, GarcíaVázquez E, Borrell YJ. 2015. Genetic diversity and connectivity patterns of harvested and aquacultured molluscs in estuaries from Asturias (northern Spain). Implications for management strategies. Aquaculture Research. 14 pages. doi: $10.1111 /$ are. 12745

Tamura K, Nei M. 1993. Estimation of the number of nucleotide substitutions in the control region of mitochondrial
DNA in humans and chimpanzees. Molecular Biology and Evolution 10:512-26.

Tamura K, Stecher G, Peterson D, Filipski A, Kumar S. 2013. MEGA6: Molecular Evolutionary Genetics Analysis Version 6.0. Molecular Biology and Evolution 30:2725-29. doi:10. 1093/molbev/mst197

Underwood AJ, Denley EJ. 1984. Paradigms, explanations and generalizations in models for the structure of inter-tidal communities on rocky shores. In: Strong D, Simberloff DS, Abele L, Tristle A, editors. Ecological Communities. Princeton, NJ: Priceton University Press, p 152-80.

Valentini A, Pompanon F, Taberlet P. 2008. DNA barcoding for ecologists. Trends in Ecology and Evolution 24(2):110-17. doi:10.1016/j.tree.2008.09.011

Wolff WJ. 1999. Exotic invaders of the meso-oligohialine zone of estuaries in the Netherlands: why are there so many? Helgoländer Meersuntersuchungen. 52:393-400. doi:10. 1007/BF02908913

WoRMS Editorial Board. 2014. World Register of Marine Species. http://www.marinespecies.org (accessed 18 May 2015). 